\title{
Social Entrepreneurship: Kewirausahaan Perempuan di Bogor melalui Pengolahan Kain Perca Limbah Konveksi menjadi Aksesoris
}

\author{
Resista Vikaliana $^{1}$, Asti Andayani2 \\ Institut Ilmu Sosial dan Manajemen STIAMI Jakarta ${ }^{1}$; STIE Dewantara Bogor ${ }^{2}$ \\ resistav31@gmail.com ${ }^{1}$, astiandayani83@yahoo.com ${ }^{2}$
}

\begin{abstract}
Social entrepreneurship can be a solution or model of community empowerment, especially women, in the handicraft industry. The handicraft industry was chosen because it was indicated in demand by the Bogor community and potentially contributed to the absorption of Bogor manpower and investment. Based on this, community service activities are conducted on two target communities / partners, consisting of Children of Putri Bunda Orphanage, Dramaga and Mothers of PKK Situ Ilir Village, Cibungbulang District with the aim of forming Social entrepreneurship as a model of women empowerment through making the accessories based on patchwor. The activity is done through several stages, which begins with socialization, held the training, after the entrepreneur walk, conducted assistance. The result of this community service activity is the formation of entrepreneur or business to make accessories made from woven waste patchwork. Social entrepreneurship can be a solution to the improvement of the economy through community empowerment, especially women.
\end{abstract}

Keywords: Social entrepreneurship; Women; Patchwork handycraft

\begin{abstract}
Abstrak
Kewirausahaan sosial dapat menjadi solusi atau model pemberdayaan masyarakat, terutama perempuan, dalam industri kerajinan. Industri kerajinan dipilih karena diindikasikan dalam permintaan oleh masyarakat Bogor dan berpotensi berkontribusi terhadap penyerapan tenaga kerja dan investasi Bogor. Berdasarkan hal tersebut, kegiatan pelayanan masyarakat dilakukan pada dua komunitas sasaran / mitra, terdiri atas Panti Asuhan Anak Putri Putri, Dramaga dan Ibu PKK Desa Situ Ilir, Kabupaten Cibungbulang dengan tujuan membentuk kewirausahaan sosial sebagai model pemberdayaan perempuan melalui pembuatan aksesoris berbasis kain perca Kegiatan ini dilakukan melalui beberapa tahap, diawali dengan sosialisasi, mengadakan pelatihan, setelah para usaha berjalan, dilakukan pengabdian. Hasil dari kegiatan pengabdian masyarakat ini adalah pembentukan pengusaha atau bisnis untuk membuat aksesoris yang terbuat dari kain perca dari limbah konveksi. Kewirausahaan sosial dapat menjadi solusi untuk peningkatan ekonomi melalui pemberdayaan masyarakat, terutama perempuan.
\end{abstract}

Kata kunci: Kewirausahaan social; Wanita; Kerajinan kain perca 


\section{A. PENDAHULUAN}

Indonesia saat ini masih memiliki 3 masalah dalam mencapai pertumbuhan ekonomi yang optimal, yakni masalah sosial kemiskinan, ketimpangan sosial, dan pengangguran. Hal ini disampaikan oleh Menteri Tenaga Kerja, Hanif Dhakiri (2017). Secara statistik, angka 3 hal tersebut sudah mengalami penurunan, angka kemiskinan turun dari 11,1\% menjadi $10,8 \%$. Ketimpangan menurun dari $0,41 \%$ jadi $0,39 \%$, pengangguran juga turun dari $6,18 \%$ jadi $5,6 \%$.

Keprihatinan masyarakat terha-dap keadaan sosial negara, mengawali terbentuknya social entrepreneurship/ kewirausahaan sosial. Kewirausahaan sosial meru-pakan model bisnis baru, yang meng-kombinasikan semangat besar dalam misi sosial dengan disiplin, inovasi dan keteguhan seperti yang lazim ditemukan di dunia bisnis. Dapat dikatakan kewirau-sahaan sosial menggunakan sikap mental wirausaha demi tujuan-tujuan sosial. Social entrepreneurship (kewirausahaan sosial) dapat dipahami sebagai seseorang yang melihat permasalahan sosial sebagai sesuatu yang harus diperbaiki dengan menggunakan kemampuan entrepreneurship yang dimiliki untuk melakukan perubahan sosial. Permasalahan tersebut terutama pada bidang kesejah-teraan, pendidikan dan kesehatan.

Social entrepreneurs tidak hanya berorientasi pada keuntungan saja, melainkan juga pada kesejahteraan masyarakat, sehingga dapat menjadi solusi alternatif yang kreatif, karena tidak hanya berorientasi pada keuntungan belaka akan tetapi juga kesejahteraan masyarakat. Melalui kewirausahaan sosial, masalah ekonomi Indonesia dapat sedikit teratasi, karena masyarakat akan terlibat langsung dalam menjadi pelaku bisnis dan keuntungannya akan dikembalikan lagi ke masyarakat untuk dikembangkan. Dengan demikian, social entrepreneur juga dapat sedikit membantu dalam mengatasi masalah-masalah pereko-nomian di suatu negara. Masyarakat menjadi terlibat langsung sebagai pelaku bisnis yang keuntungannya akan dikembalikan lagi kepada masyarakat untuk dikembangkan.

Kegiatan pengabdian masyarakat berbasis social entrepreneurship atau kewirausahaan sosial dilakuan oleh Saleh dkk (2015) berjudul Pengembangan Program Inkubator Wirausaha Sosial di Kecamatan Cibungbulang, Kabupaten Bogor. Berdasarkan hasil kajian diperoleh bahwa: 1) Karakteristik pelaku usaha mikro kecil di Posdaya didominasi pada umur produktif dengan lulusan SMA, memi-liki tanggungan keluarga 3-4 orang; 2) Kemitraan usaha dan bisnis masyarakat telah dilakukan dengan pemerintah daerah melalui BKP5K Kabupaten Bogor, MT Farm, Kam-pung Ternak Dompet Dhuafa, P2MKP KKP, Koperasi Posdaya Indonesia, IPB, BRI Cabang Bogor; 3) Pelatihan dan pendampingan bagi pelaku usaha mikro kecil difokuskan pada pela-tihan motivasi dan manajemen keuangan usaha, pelatihan desain kemasan, pendampingan kelemba-gaan, dan pendampingan teknis.

Wirausaha Indonesia saat ini (2017) berjumlah 3,1\% dari populasi 252 juta penduduk Indonesia (Menteri Koperasi, 2017). Berdasarkan data BPS 2016 tentang jumlah wirausaha non pertanian yang menetap mencapai 7,8 juta orang atau 3,1 persen. Dengan demikian tingkat kewi-rausahaan Indonesia telah melampaui 2 persen dari populasi penduduk, sebagai syarat minimal suatu masyarakat akan sejah-tera. Rasio wirausaha sebesar 3,1 persen itu masih lebih rendah dibandingkan dengan negara 
lain seperti Malaysia 5 persen, China 10 persen, Singapura 7 persen, Jepang 11 persen maupun AS yang 12 persen.

Windirah (2017) meneliti tentang pengaruh perilaku kewirausahaan terhadap kinerja usaha pada perempuan wirausaha (Studi Pengrajin Usaha Kecil dan Menengah Kota Bogor). Penelitian didasarkan pada masalah pendapatan yang diperoleh pengrajin belum menunjukkan peningkatan yang signifikan dalam beberapa tahun terakhir. Hal ini diduga karena tidak adanya peningkatan kinerja usaha yang disebabkan oleh perilaku kewirausahaan pada perempuan pengrajin. Selain itu, faktor internal dan eksternal juga mampu menyebabkan hasil pembentukan perilaku kewirausahaan. Penelitian ini bertujuan untuk menganalisis hubungan antara faktor internal dan eksternal terhadap perilaku kewirausahaan pada perempuan pengrajin, serta menganalisis pengaruh perilaku kewirausahaan terhadap kinerja usaha pada industri kerajinan di Kota Bogor.

Hasil penelitian menunjukkan faktor internal berpengaruh nyata dan positif terhadap perilaku kewirausahaan. Atribut faktor internal yaitu pendidikan, pengalaman, kepemilikan sarana dan prasarana dan persepsi terhadap usaha. Artinya setiap peningkatan yang terjadi pada pendidikan, pengalaman, kepemilikan sarana dan prasarana dan persepsi terhadap usaha mampu meningkatkan pula perilaku kewirausahaan pada perempuan pengrajin. Hasil kedua menunjukkan perilaku kewirausahaan berpengaruh nyata dan positif terhadap kinerja usaha industri kerajinan, atribut perilaku kewirausahaan adalah kete-kunan berusaha dan keberanian mengambil resiko usaha. Artinya setiap peningkatan yang terjadi pada ketekunan berusaha dan keberanian mengambil risiko usaha dapat meningkatkan pula kinerja usaha pada industri kerajinan Kota Bogor.
Data UKM pada Pemerintahan Kota Bogor (2015) dan Kabupaten Bogor dalam Angka (2015) menunjukkan bahwa industri kerajinan merupakan industri pertama dalam menyumbang penyerapan tenaga kerja dan investasi Bogor. Akan tetapi, Kota Bogor memiliki unit industri kerajinan jauh lebih banyak (2045 unit) dibandingkan dengan Kabupaten Bogor (615 unit). Jumlah industri kerajinan yang banyak mengindikasikan adanya minat yang tinggi oleh masyarakat Kota Bogor terhadap kerajinan.

Pada awalnya, kegiatan pengabdian masyarakat ini direncanakan pada empat tempat sasaran. Keempat tempat tersebut adalah: 1) Ibu-ibu Pengajian di sekitar Taman Bacaan KBM Gadog, Ciawi. 2) Ibu-ibu Anggota PKK Desa Situ Ilir Kecamatan Cibungbulang. 3) Anak-anak Panti Asuhan Putri Bunda, Dramaga. 4) Anak-anak Santri Pesantren Tahfidz Yatim dan Dhuafa Nurul Iman, Ciomas. Namun, yang difokuskan pada penulisan ini adalah Ibu-ibu PKK Desa Situ Ilir, Kecamatan Cibung-bulang dan anak-anak Panti Asuhan Putri Bunda. Mitra dalam kegiatan pengabdian masyarakat ini berpotensi untuk berwirausaha. Hasil observasi awal dan wawancara, para mitra merupakan komunitas masyarakat yang kurang berdaya secara ekonomi.

Berdasarkan pemaparan sebelumnya, social entrepreneurship/ kewirausahaan sosial dapat dijadikan solusi atau model pemberdayaan masyarakat, khususnya perempuan, pada industri kerajinan. Industri kerajinan dipilih karena diminati oleh masyarakat Bogor dan berpotensi menyumbang penyerapan tenaga kerja dan investasi Bogor. Tujuan kegiatan pengabdian kepada masyarakat ini adalah membentuk Social entrepreneurship/ kewirausahaan sosial sebagai model pem-berdayaan perempuan 
melalui pembuatan asesoris berbahan dasar kain perca pada tempat sasaran/ mitra.

\section{B. PELAKSANAAN DAN METODE}

Kegiatan dilakukan dari Bulan Maret 2015 sampai dengan Maret 2016. Mitra dalam kegiatan ini terdiri atas Anakanak Panti Asuhan Putri Bunda, Dramaga berjumlah 25 orang dan Ibu-ibu Anggota PKK Desa Situ Ilir Kecamatan Cibungbulang berjumlah 40 orang. Program kegiatan ini dilakukan bekerja sama dengan Komunitas Berbagi Manfaat/ KBM. KBM adalah komunitas filantropi berpusat di Bogor yang salah satu programnya adalah memberdayakan masyarakat, melalui kewirausahaan.

Metode yang digunakan dalam pemecahan permasalahan adalah melalui pendampingan kewirausahaan melalui Kewirausahaan Sosial. Kegiatan dilakukan dengan memberdayakan masyarakat sasaran/mitra dari kegiatan hulu sampai kegiatan hilir dalam kewirausahaan. Kegiatan dilakukan melalui beberapa tahap, yakni: 1) Diawali dengan sosialisasi; 2) Pelaksanaan pelatihan-pelatihan; 3) Setelah wirausaha berjalan, dilakukan pendam-pingan.

Tahapan kegiatan pada Anak-anak Panti Asuhan Putri Bunda, Dramaga adalah: 1) Sosialisasi Program dengan materi Motivasi Wirausaha; 2) Pelatihan Produksi Pembuatan Asesoris (bros, karet rambut, gantungan kunci dan lainnya); 3) Pelatihan SDM, Keuangan, dan Pemasaran; 4) Pelatihan Creative Thinking; 5) Pendampingan usaha. Sedangkan tahapan padalbu-ibu Anggota PKK Desa Situ Ilir, Kecamatan Cibungbulang adalah: 1) Sosialisasi Program dengan materi Motivasi Wirausaha; 2) Sosialisasi tentang pemasaran; 3) Pelatihan Produksi Pembuatan Asesoris (bros, tempat jarum pentul, dan lainnya); 4) Pendampingan usaha.

\section{HASIL DAN PEMBAHASAN}

Menguraikan tentang dampak nyata dari hasil kegiatan (produk/ barang atau jasa yang dihasilkan mitra). Uraian hasil harus terukur (dapat dilakukan melalui kuesioner, pre-test, dan post-test, pengamatan produk yang dihasilkan, respon mitra, dan lain-lain). Faktor-faktor pendorong atau penghambat pelaksanaan program.

Pada awalnya, kegiatan ini direncanakan pada empat tempat sasaran. Keempat tempat tersebut adalah: 1) Ibuibu Pengajian di sekitar Taman Bacaan KBM Gadog, Ciawi; 2) Ibu-ibu Anggota PKK Desa Situ Ilir Kecamatan Cibungbulang; 3) Anak-anak Panti Asuhan Putri Bunda, Dramaga; 4) Anakanak Santri Pesantren Tahfidz Yatim dan Dhuafa Nurul Iman, Ciomas. Pada Ibu-ibu Pengajian di sekitar Taman Bacaan KBM Gadog, Ciawi, program kewirausahaan sosial ini tidak dapat dilaksanakan. Setelah dilakukan pendekatan secara persuasif dengan tokoh masyarakat setempat, kader PKK dan Pengelola Pengajian, juga dilakukan sosialisasi pada Ibu-ibu Pengajian, kegiatan kewirausahaan sosial dengan fokus pada kerajinan asesoris dari perca tidak sesuai dengan keinginannya. Mereka lebih meminati kegiatan hilirisasi yakni pemasaran produk.

Tahapan kegiatan pada Anak-anak Panti Asuhan Putri Bunda, Dramaga adalah:

1. Sosialisasi Program dengan materi Motivasi Wirausaha

Kegiatan ini melibatkan penulis dan relawan KBM. Kegiatan ini berjalan baik, ditandai dengan minat anak-anak panti untuk berwirausaha. 


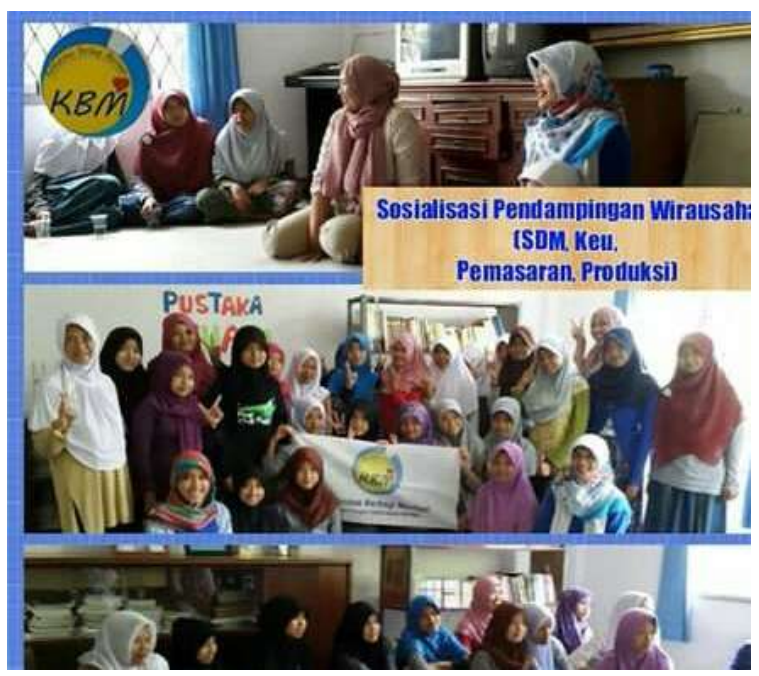

Gambar 1. Sosialisasi Program dan Motivasi Wirausaha

2. Pelatihan Produksi Pembuatan Asesoris (bros, karet rambut, gantungan kunci dan lainnya)

Pelatihan produksi dilakukan oleh penulis selama dua kali pertemuan. Bahan diperoleh dari limbah atau sisa produksi konveksi (kain perca) dan alat-alat didanai oleh KBM.

3. Pelatihan SDM, Keuangan, dan Pemasaran (gambar 4 pada lampiran). Pelatihan ini melibatkan penulis dan narasumber dari KBM, dilakukan selama tiga kali pertemuan. Pelatihan ini dilakukan, setelah produksi berjalan lancar dan stabil, serta produk mulai dipasarkan. Pemasaran dilakukan dengan pemasaran langsung dan dengan men-display produk dalam etalase di pintu masuk panti.

4. Pelatihan Creative Thinking

Pelatihan ini dilakukan satu kali pertemuan, dengan tujuan memotivasi dan membuka wawasan anak-anak panti tentang berpikir kreatif. Kreativitas adalah salah satu unsur dalam kewirausahaan. Dengan pelatihan ini, anak-anak panti mampu mengembangkan produk dan pengelolaan usaha yang sudah dijalankan.

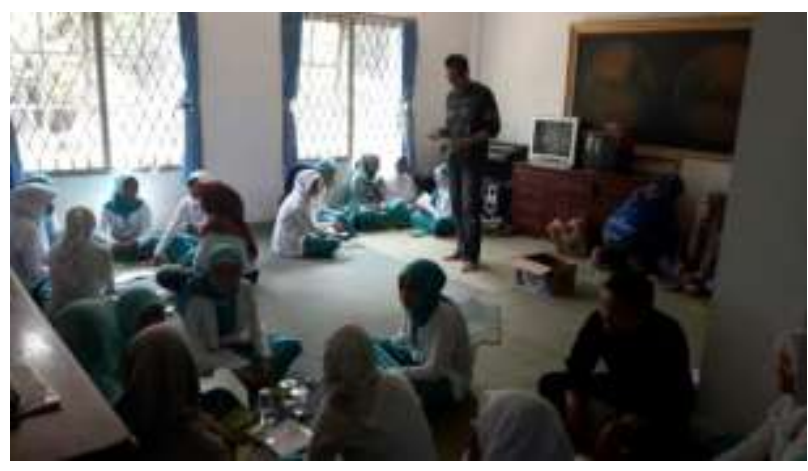

Gambar 2. Dinamika Kelompok pada Pelatihan Creative Thinking

5. Pendampingan usaha.

Pendampingan usaha dilakukan untuk memonitor kualitas dan membantu bila terdapat kesulitan. Pendampingan dilakukan selama 6 bulan.

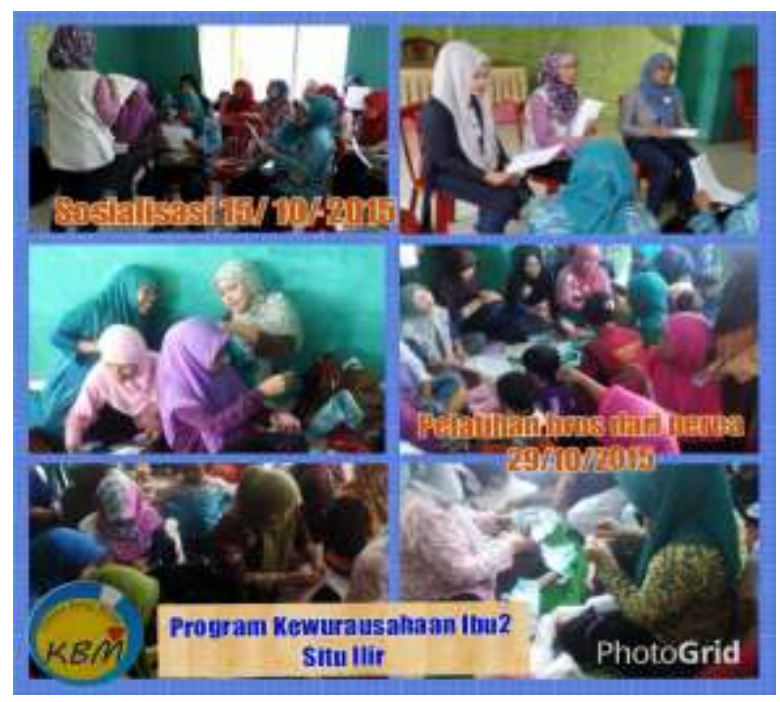

Gambar 3 Sosialisasi dan pelatihan ibu-ibu Situ Ilir

Sedangkan tahapan pada ibu-ibu Anggota PKK Desa Situ Ilir, Kecamatan Cibungbulang adalah: 1) Sosialisasi Program dengan materi Motivasi Wirausaha dilakukan satu kali pertemuan. Sosialisasi dilakukan oleh penulis; 2) Sosialisasi tentang pemasaran. Sosialisasi ini dilakukan dalam satu kali pertemuan; 3) Pelatihan Produksi Pembuatan Asesoris (bros, tempat jarum pentul, dan lainnya). 
Pelatihan produksi dilakukan oleh penulis selama satu kali pertemuan. Pelatihan hanya satu kali, karena Ibu-ibu Anggota PKK telah memiliki kemampuan menjahit dan berkreasi yang cukup untuk menghasilkan produk yang layak jual. Bahan diperoleh dari limbah atau sisa produksi konveksi (kain perca) dan alatalat didanai oleh KBM. 4) Pendampingan usaha dilakukan untuk memonitor kualitas dan membantu bila terdapat kesulitan. Pendampingan dilakukan selama 3 bulan.

\section{PENUTUP}

\section{Simpulan}

\section{Social}

entrepreneurship/

kewirausahaan sosial dapat dijadikan solusi atau model pemberdayaan masyarakat, khususnya perempuan, pada industri kerajinan. Industri kerajinan dipilih karena terindikasi diminati oleh masyarakat Bogor dan berpotensi menyumbang penyerapan tenaga kerja dan investasi Bogor. Berdasarkan hal tersebut, kegiatan pengabdian masyarakat ini dilakukan pada dua masyarakat sasaran/mitra, terdiri atas Anak-anak Panti Asuhan Putri Bunda, Dramaga dan Ibuibu Anggota PKK Desa Situ Ilir Kecamatan Cibungbulang. Kegiatan dilakukan melalui beberapa tahap, yakni sosialisasi kegiatan, pelaksanaan pelatihan-pelatihan, dan proses pendampingan.

Hasil dari kegiatan pengabdian masyarakat ini adalah terbentuknya wirausaha atau bisnis membuat asesoris berbahan dasar kain perca limbah konveksi. Kewirausahaan sosial dapat menjadi solusi terhadap peningkatan perekonomian melalui pemberdayaan masyarakat, khususnya perempuan.

$\begin{array}{lr}\text { Saran } & \\ \text { Perencanaan } & \text { program } \\ \text { pemberdayaan masyarakat } & \text { seharusnya } \\ \text { dilaksanakan bersama mitra, } & \text { sehingga } \\ \text { program-program yang tersusun } & \text { tegrapanan solusi bagi masalah mitra. }\end{array}$ \\ Saran pemberdayaan masyarakat seharusnya dilaksanakan bersama mitra, sehingga merupakan solusi bagi masalah mitra.}




\section{E. DAFTAR PUSTAKA}

Badan Pusat Statistik Jawa Barat. 2012. Jumlah Unit Usaha Kecil dan Menengah Tahun 2012. Jawa Barat.

Saleh A. Warcito US. 2015. Pengembangan Program Inkubator Wirausaha Sosial di Kecamatan Cibungbulang, Kabupaten Bogor. Jurnal Ilmiah Pengabdian kepada Masyarakat Agrokreatif. 1: 88-95.

Windirah N, Suwarsinah, Adhi HK, dan Kilat A. 2017. Pengaruh Perilaku Kewirausahaan terhadap Kinerja Usaha pada Perempuan Wirausaha (Studi Pengrajin Usaha Kecil dan Menengah Kota Bogor). http://repository.ipb.ac.id/handle/1 23456789/85493- Diunduh 24 November 2018. 